IRA-International Journal of Technology \& Engineering

ISSN 2455-4480; Vol.09, Issue 03 (December 2017)

Pg. no. 27-36

Institute of Research Advances

https://research-advances.org/index.php/IRAJTE

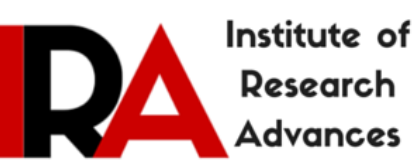

\title{
Water-Use and Conservation in the Commercial Vehicle Washing Industry in Urban Ghana: The Case of Cape Coast Metropolis
}

\author{
J. H. Quayson ${ }^{1} \&$ E. Awere ${ }^{2 \#}$ \\ \#corresponding author. \\ Type of Review: Peer Reviewed. \\ DOI: http://dx.doi.org/10.21013/jte.v9.n3.p2
}

${ }^{1}$ Lecturer, Department of Building Technology, Cape Coast Technical University, Ghana.

${ }^{2}$ Lecturer, Department of Civil Engineering, Cape Coast Technical University, Ghana.

\section{How to cite this paper:}

Quayson, J.H., Awere, E. (2017). Water-Use and Conservation in the Commercial Vehicle Washing Industry in Urban Ghana: The Case of Cape Coast Metropolis. IRA International Journal of Technology \& Engineering (ISSN 2455-4480), 9(3), 27-36. doi:http://dx.doi.org/10.21013/jte.v9.n3.p2

(C) Institute of Research Advances.

\section{(cc)) BY-NC}

This work is licensed under a Creative Commons Attribution-Non Commercial 4.0 International License subject to proper citation to the publication source of the work.

Disclaimer: The scholarly papers as reviewed and published by the Institute of Research Advances (IRA) are the views and opinions of their respective authors and are not the views or opinions of the IRA. The IRA disclaims of any harm or loss caused due to the published content to any party.

Institute of Research Advances is an institutional publisher member of Publishers Inter Linking Association Inc. (PILA-CrossRef), USA. The institute is an institutional signatory to the Budapest Open Access Initiative, Hungary advocating the open access of scientific and scholarly knowledge. The Institute is a registered content provider under Open Access Initiative Protocol for Metadata Harvesting (OAI-PMH).

The journal is indexed \& included in WorldCat Discovery Service (USA), CrossRef Metadata Search (USA), WorldCat (USA), OCLC (USA), Open J-Gate (India), EZB (Germany) Scilit (Switzerland), Airiti (China), Bielefeld Academic Search Engine (BASE) of Bielefeld University, Germany, PKP Index of Simon Fraser University, Canada. 


\begin{abstract}
Commercial vehicle washing businesses have gained popularity in urban Ghana. Most vehicle washing bays operating in the Cape Coast Metropolis rely on Ghana Water Company Limited $(G W C L)$ for their water supply. With increasing vehicular numbers, the pressure on the limited safe water quantities is likely to increase. There is the need to regulate the operations of the commercial vehicle washing industry to ensure water conservation and its associated environmental and social impacts. This study is aimed at assess the water-use and conservation strategies in the commercial vehicle washing industry in the Cape Coast Metropolis. The study focused on all the sixteen (16) commercial vehicle washing bays in the Cape Coast metropolis which are registered with and certified by the Metropolitan Assembly and are also members of the Vehicle Washing Bay Operators Association, Cape Coast Branch. Data was collected through the use of pre-tested questionnaire and interview guide as well as personal observation and measurement. A total of Thirty-two (32) questionnaires were distributed to the General Managers and Operation Managers of all the 16 washing bays in the metropolis. In addition, officials of Cape Coast Metropolitan Assembly (CCMA) and Central Regional office of Environmental Protection Agency (EPA) were interviewed. Trained Research Assistants were assigned to each vehicle washing bay for one week including Saturdays and Sundays to count the number of vehicles washed daily and the quantity of water used for washing. The study revealed that the most common technique used by the washing bays is the manual and semi-automatic washing process. On the average, the quantity of water required for washing vehicles ranges between 162.0 litres for saloon vehicles and 532.0 litres for tipper trucks. A minimum of 96 vehicles are washed daily utilizing approximately 19,346.00 litres (19.346 m3) of water. There are no water efficiency and wastewater reclamation regulations in place for the vehicle washing industry. It is concluded that the existing commercial vehicle washing facilities in use does not ensure efficient water use and conservation.
\end{abstract}

Keywords: Vehicle washing bay, Water-use, water conservation, Ghana

\title{
Introduction
}

Water is an essential resource used for both domestic and industrial purposes. Water is treated to remove specific contaminants to make it wholesome for the intended use. However, access to quality water in adequate quantities is a challenge for most countries around the globe. A Statement issued by Brown [1] on World Water Day and White House Water Summit attests that no matter where you live, access to water is not guaranteed. Ghizellaoui, et al. [2] concluded that, in view of the importance of treated water and the limited capacity for its treatment and production, there is the need to manage it judiciously to avoid wastage and pollution. The commercial vehicle washing industry is one of the industries that requires large quantities of quality water for their operations [3]. In this business, water is required for cleaning the interior and exterior of motor vehicles, and other accessories. The quantity of water used is dependent to a large extent on the technology used for washing.

The establishment of vehicle washing bays has gained popularity in Ghana, especially in the Capital Cities where there is high concentration of vehicles. Janik and Kupiec [4] reports that commercial vehicle washing facilities employing mechanical devices have become very common and are located at designated areas in urban areas. The activities of the vehicle washing bays involves the use of chemicals, generating wastewater with a high concentration of surfactants, oils, greases, waxes and other contaminants, which make these effluents toxic to aquatic life. The large volume of wastewater generated ultimately flows into our water bodies thereby polluting them $[5,6]$. The use of detergents in vehicle washing activities have been blamed for the widespread phosphate contamination in the streams in Kumasi [7]. According to California Environmental Protection Agency [8], pollution of water bodies by untreated vehicle wash is a prominent and serious environmental hazard. In Ghana, the Environmental Protection Agency ACT of 1994 (ACT 490) prescribes standards and guidelines relating to safeguarding environmental pollution including the discharge of wastes and control of toxic substances. Unfortunately, Abraham [9] emphasized that most vehicle washing bays are violating the Environmental Protection Agency ACT by discharging untreated wastewater directly into streams and rivers.

Most vehicle washing bays operating in the Cape Coast Metropolis relies on Ghana Water Company Limited (GWCL) for water supply. This means that there is intense pressure on Managers of GWCL to 
meet the domestic and industrial water needs of the people whiles keeping the water tariffs within reasonable range. According to Appiah-Kubi [10], Ghana Water Company Limited (GWCL) will soon close down most of the vehicle washing bays in the country after official approval by the Metropolitan Authority's and the Environmental Protection Agency to conserve treated water. With increasing vehicular numbers in Ghana, the pressure on the limited safe water quantities is likely to increase. Tetteh-Addison [11] posits that, vehicle-population ratio in Ghana has grown from 31 vehicles per 1,000 population in 2002 , to about 44 vehicles per 1,000 population in 2008. As at March 2012, the total number of registered vehicles in Ghana stood at approximately 1,425,900.

The high water demand by vehicle washing bays and the consequent environmental impact associated with the discharge of untreated wastewater from vehicle washing operations has pushed many countries in the world to regulate the activities of the vehicle washing bays. Even though various countries have different approach for regulating the activities of the vehicle bays, the approaches vary between certification programs, water saving rebates and regulations. These policies are conducted by water operators, water agencies, municipalities and vehicle wash associations. In addition to restrictive legislation, rising water tariffs are pushing the vehicle washing bay operations to invest in process-integrated solutions [12, 13]. It is perceived that inefficient washing method leads to more water per wash and consequently more wastewater generated in the developing world.

This study is aimed at assess the water-use and conservation strategies in the commercial vehicle washing industry in the Cape Coast Metropolis. The study focused on the specific objectives of (1) determining the existing facilities in use at various vehicle washing bays, (2) determining the sources and average quantity of water used by vehicle washing bays, and (3) assessing the water conservation strategies put in place by the washing bay operators.

\section{Methodology}

\section{Study Area}

The Cape Coast Metropolis of Ghana is bounded to the South by the Gulf of Guinea, West by the Komenda-Edina-Eguafo-Abrem Metropolis, East by the Abura-Asebu-Kwamankese District and North by the Twifu-Hemang-Lower Denkyira District. The Metropolis occupies an Area of approximately 122 square kilometres, with the farthest point at Brabadze, about 17 kilometres from Cape Coast. The Capital of the Metropolis, Cape Coast, is also the Capital of the Central Region. The Metropolis is divided into two Sub-Metros: Cape Coast South and Cape Coast North Sub-Metros. The Cape Coast Metropolis with a population of 169,894 according to 2010 census [14] receives it water supply mainly from Ghana Water Company Limited (GWCL) through household connections and stand pipes (private and public). The production of water (from surface water impoundment) by GWCL is carried out at the Brimsu treatment plant for distribution to the metropolis. There are sixteen (16) (9 bays in Cape Coast South and 7 bays in Cape Coast North) vehicle washing bays in the Cape Coast metropolis which are registered with and certified by the Metropolitan Assembly and are members of the Vehicle Washing Bay Operators Association, Cape Coast Branch. In addition, there are other individuals who have neither registered with the Metropolitan Assembly nor the Vehicle Washing Bay Operators Association but engage in illegal vehicle washing along river banks and marshy areas. Cape Coast was selected for the study because it is the first Capital of Ghana and the fifth largest city in Ghana and so provides an opportunity for the study.

\section{Population}

The study was restricted to vehicle washing bays in the Cape Coast Metropolis who have registered with and certified by the Metropolitan Assembly and are members of the Vehicle Washing Bay Operators Association, Cape Coast Branch. All the 16 vehicle washing bays in the metropolis were selected for this study. For each of the Washing Bays, both the General Managers and Operation Managers/Supervisors took part in the study. Both the general managers and operation managers/supervisors were selected as respondents for the study because the General Managers own the businesses and provides all resources needed for the business whiles the Operation Managers see to the day-to-day running of the washing bays. 


\section{Research Approach}

Both census and purposive sampling techniques were used in this study. Census technique was used to select the entire population of registered vehicle washing bays for the study. Gay and Mills [15] have stated that, data collected through census technique gives opportunity to the researcher to have an intensive study and gather a lot of knowledge about a problem. It also offers a higher degree of accuracy in data collected especially when the population is small (less than 100). Purposive sampling technique was then used to select the general managers and operation Managers from each of the vehicle washing bays. A total of Thirty-two (32) respondents made up of General Managers and Operation Managers of all the 16 washing bays were selected. In addition to the vehicle washing bay operators, officials of Cape Coast Metropolitan Assembly (CCMA) and Central Regional office of Environmental Protection Agency (EPA) participated in the research.

\section{Research Instruments}

Data for the research was gathered through questionnaire administration, interviews and personal observation. The questionnaires and interview guide were pre-tested through preliminary interviews and questionnaire administration. The comments received during the pretesting were used to finalize the questionnaire and interview guide.

The questionnaire focused on existing vehicle washing bay facilities water demand for vehicle washing and water conservation or reclamation approaches employed. The questionnaire was made of both open-ended and closed-ended questions which were self-administered except in the instance where the respondents could read and understand the questions properly. The choice of personal administration of the questionnaires was to ensure maximum response rate. The used of the questionnaires allowed both subjective and objective views of respondents to be sourced.

An unstructured interview was conducted using the pretested interview guide. This technique was used on the officials of CCMA and EPA to ascertain the institutional arrangements for regulating the operations of vehicle washing bays.

To obtain an estimate of the actual number of vehicles washed and the quantity of water used, trained Research Assistants were placed at each of the vehicle washing bays for one week including Saturdays and Sundays. The operation modes followed by these facilities may be grouped in two main categories, according to the way water is provided: 1) Use of buckets to throw water to the cars ("bucket-fulls"). The number of containers used during the process was counted and multiplied by the average volume of a bucket. 2) Use of hose or pressure gun connected to the water supply system or to a water pump. The water used per vehicle washed was estimated by means of measuring the flow rate supplied by the washing system (hoses and/or pressure guns) and recording the time of operation. At the start and close of daily operations, the observers also recorded the water meter readings. These were used to confirm the average quantity of water used per day.

\section{Methodology}

The first research question seeks to evaluate the existing facilities in use at various vehicle washing bays.

\section{Method of Vehicle Washing}

Table 1 presents the results of method of vehicle washing and the common technology in use. 
Table 1: Existing Vehicle Washing Bays Facilities in Use

\begin{tabular}{|c|c|c|c|c|c|c|c|c|c|c|}
\hline \multirow{3}{*}{ Description } & \multicolumn{10}{|c|}{ Responses } \\
\hline & \multicolumn{2}{|c|}{$\begin{array}{c}\text { Manual } \\
\text { vehicle } \\
\text { wash }\end{array}$} & \multicolumn{2}{|c|}{$\begin{array}{c}\text { Semi-automatic } \\
\text { wash }\end{array}$} & \multicolumn{2}{|c|}{$\begin{array}{c}\text { Automatic } \\
\text { wash }\end{array}$} & \multicolumn{2}{|c|}{$\begin{array}{c}\text { Touch-free } \\
\text { vehicle } \\
\text { wash }\end{array}$} & \multicolumn{2}{|c|}{ Total } \\
\hline & No. & $\%$ & No. & $\%$ & No. & $\%$ & №. & $\%$ & No. & $\%$ \\
\hline \multicolumn{11}{|l|}{ Type of washing } \\
\hline \multirow[t]{3}{*}{ Technology in use? } & 29 & 90.6 & 3 & 9.4 & 0 & 0 & 0 & 0 & 32 & 100 \\
\hline & \multicolumn{10}{|c|}{ Responses } \\
\hline & \multicolumn{2}{|c|}{ Bucket only } & \multicolumn{3}{|c|}{$\begin{array}{c}\text { High pressure washing } \\
\text { machine }\end{array}$} & \multicolumn{3}{|c|}{$\begin{array}{c}\text { Both bucket \& } \\
\text { high pressure } \\
\text { washing machine }\end{array}$} & \multicolumn{2}{|c|}{ Total } \\
\hline Description & No. & $\%$ & №. & & & No.. & & & No. & $\%$ \\
\hline $\begin{array}{l}\text { Facilities used in } \\
\text { washing the vehicles? }\end{array}$ & 0 & 0 & 3 & & & 29 & & & 32 & 100 \\
\hline
\end{tabular}

The results revealed that, majority of respondents (29), representing $90.6 \%$ use manual vehicle wash techniques. According to Indian National Environment Commission [16], manual vehicle washing is where vehicles are washed using bucket, air compressor, water pressure pump and specific pipes that can deliver a required amount of water pressure for effective washing. The vehicle is mounted over a ramp linked to drain to convey wastewater (usually containing soap and detergents, residues from exhaust fumes and engine oils) from the premises. The remaining 3 respondents (representing 9.4\%) affirmed using semiautomatic vehicle wash technique. This technique, according to literature, is where the vehicle is elevated by driving onto a ramp through hydraulic lift for washing [16]. Brown [17] mentions hydraulic boost or lift, air compressor, machine for servicing and water pump as some of the common equipment used in semiautomated facilities. Just like the manual vehicle washing, semi-automated washing techniques also requires utilization of manpower for the application of detergent and rinsing of vehicles [4]. The results that there is longer washing time, limited number of vehicles washed per day, possibility of excessive water and detergent use and the discharge of excessive quantity of wastewater (containing soap, sand particles, residues from exhaust fumes and engine oils, etc.) into public drains or surface waters with/without any treatment. Janik and Kupiec [4] have stated that, there are several international best practices and benchmarks for vehicle washing bay operation. They cite an example of the availability of mechanical devices which ensures that 75 litres of water is used to wash a vehicle. Indian National Environment Commission [16] supports the use of automated vehicle wash facility which is able to regulate the quantity of water and ingredient use, where less workforce is involved. The facility also allow the vehicle to be dragged into a tunnel and as it passes through the washing area, cleaning, rinsing, waxing, drying and etc., are done automatically. Approximately, 6-7minutes are spent in washing each vehicle thereby increasing the number of vehicles washed per day. It could be inferred that the various vehicle washing bays in the Cape Coast Metropolis are not using advanced facilities and techniques that are able to regulate the quantity of water and ingredient use.

\section{Number and Types of Vehicle Wash per Day}

The study revealed that the average number of vehicles washed per day varied with season, weather conditions, constant supply of water, uninterrupted power supply, etc. During the days when conditions are favourable, an average of 248 vehicles is washed daily in the metropolis. When conditions are unfavourable, an average of 96 vehicles is washed daily. 
Fig. 1 shows the types and number of vehicles washed in a day. Majority of the vehicles washed are saloon cars.

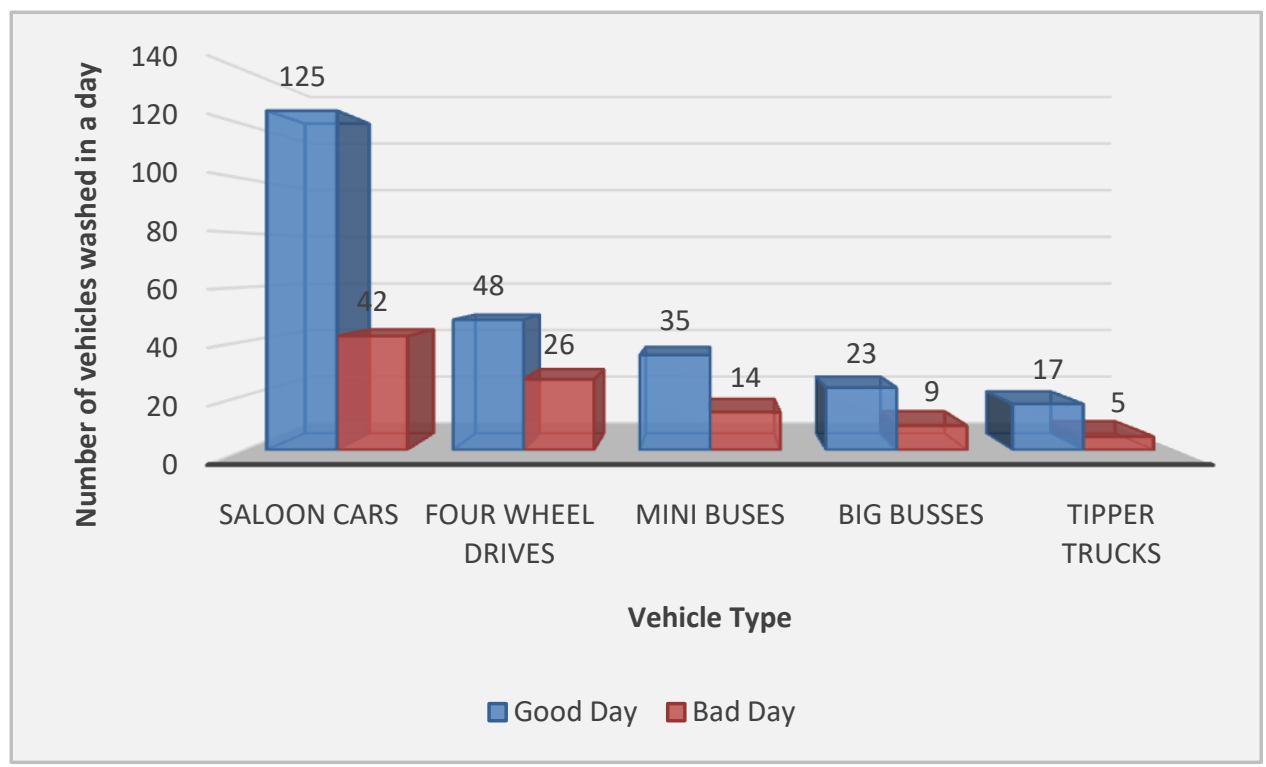

Fig. 1: Types of Vehicle Which Normally Comes For Washing in Good Business Day

\section{Sources of Water for Vehicle Operations}

Until recently, most of the carwash operators obtained their source of water from public water supply [18]. The sources of water for carwash operations in the Cape Coast metropolis are GWCL, boreholes/hand-dug wells, tanker water operators and streams/rivers. GWCL is the main source of water supply, however, high water tariffs and unreliable supply have compelled some operators to drill boreholes or hand-dug wells and patronize the services of tanker water operators to augment the supply from GWCL. Figure 2 shows the sources of water used by carwash operators in Cape Coast.

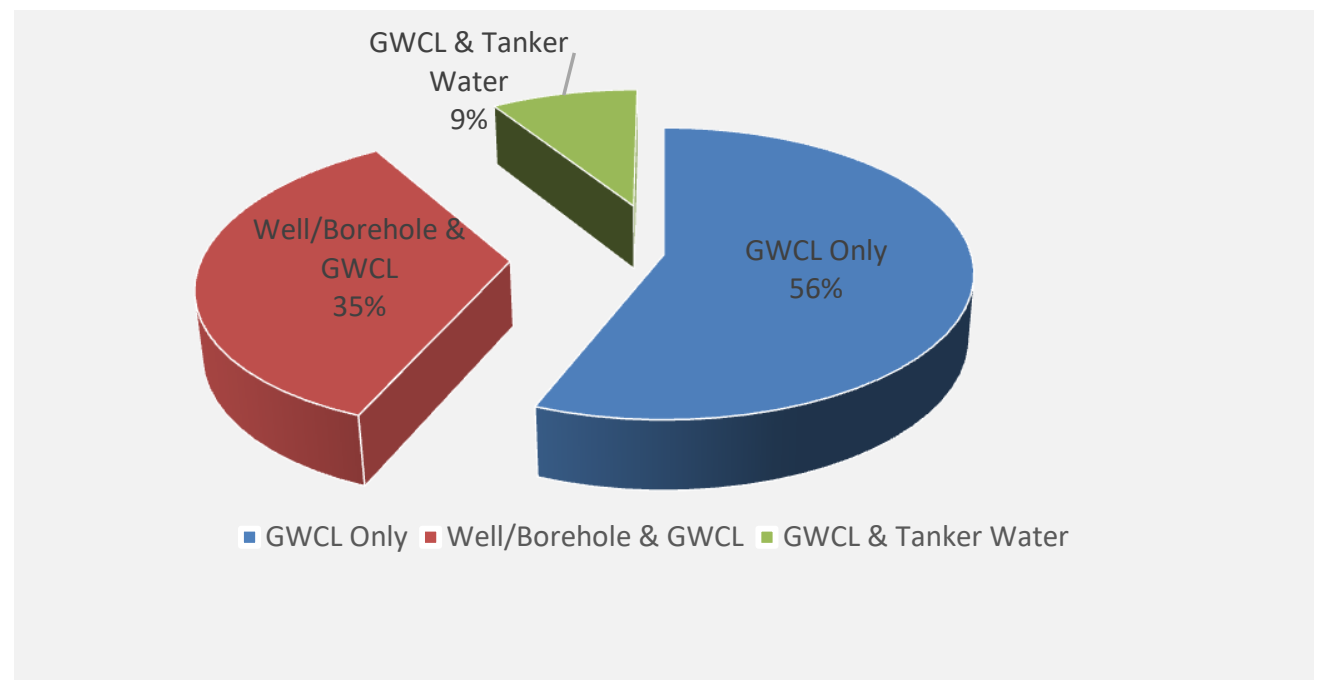

Fig. 2: Sources of Water Supply for Vehicle Washing Bay Operations

From the results shown in Fig. 2, it is clear that all the washing bays depend in part or full on GWCL for their water supply and any interruption in the supply deeply affects their operations. About $56 \%$ of the vehicle washing bays operating in the Cape Coast Metropolis depend exclusively on GWCL for water supply while the remaining $44 \%$ of vehicle washing bays supplement their supply with wells/boreholes or 
tanker water. It has been established that the water tanker operators source their water from GWCL [19, 20]. With Cape Coast Metropolis along the coast, most of the groundwater is saline, which are likely to have a negative effect on the vehicles washed. The quality of the water used for vehicle washing is as important as the quantity of the water. None of the washing bays depended on rivers or streams for their water.

\section{Average Quantity of Water Used by Vehicle Washing Bays}

Fig. 3 shows the quantity of water required to completely wash a vehicle.

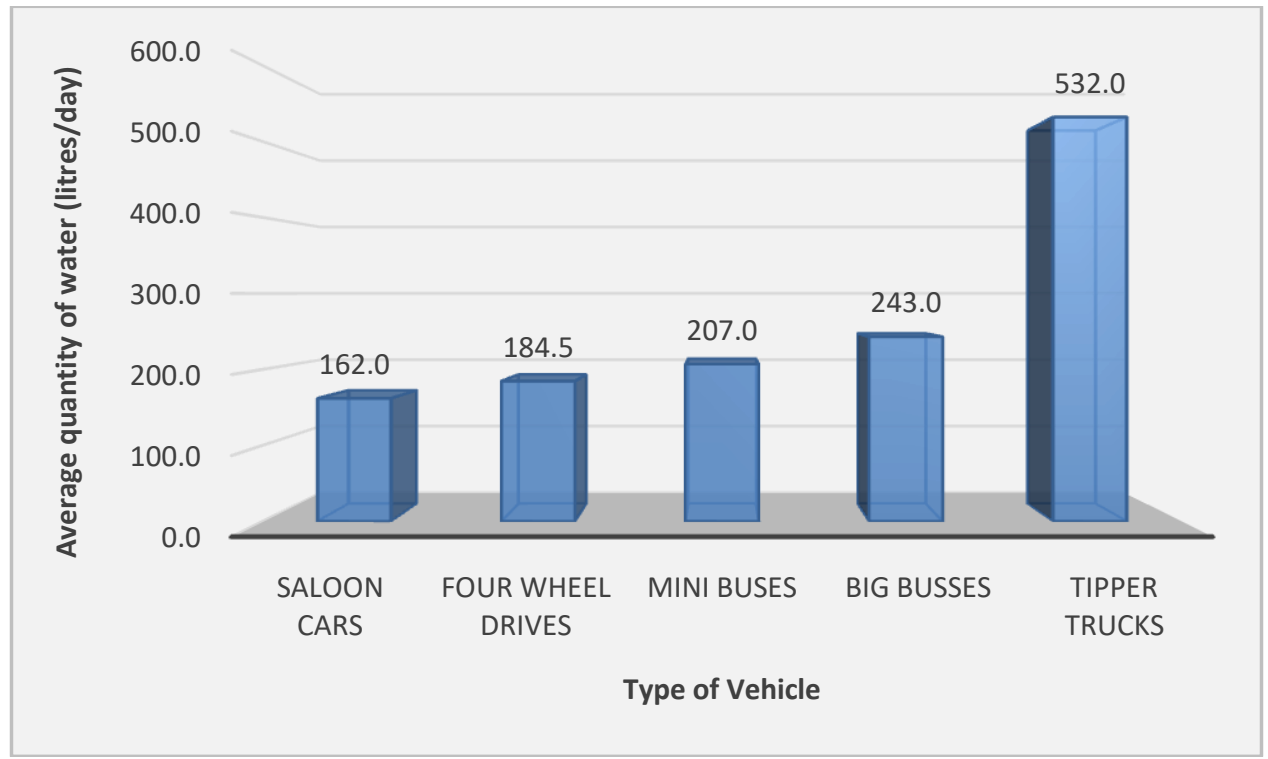

Fig. 3: Quantity of water required for vehicle washing per day

On the average, the quantity of water required for washing vehicles ranges between 162 litres for saloontype and 243 litres for big buses. Vehicles that require the highest amount of water are the tipper trucks. These vehicles require about 532 litres of water for washing. These findings are not out of range since Panizza and Cerisola [21] reports that in Italy an average of 400 litres of water is used to wash a car by hand using a hose and 150 litres per cars using conventional installations. A study conducted by Brown [17] established that water consumption per vehicle by professional vehicle wash ranged from 95.4 litres on a basic wash for a small vehicle to 192.6 litres for the works on a full size vehicle. It has been reported by Karakulski and Morawski [22] that, depending on the type of car wash installation and the size of a car, an average of 150-600 litres of water is used for washing a car. In Taiwan, $60-120$ litres of water is consumed for car washing [23]. The quantity of water required for washing a vehicle recorded in the Cape Coast metropolis is more than double the reported average daily per capita water consumption for developing countries in Africa [24, 25]. This implies that, as the economy grows vehicle washing operations are going to compete with domestic activities for water unless measures are put in place to reduce the water washed per washing and/or require vehicle washing bays to reclaim a percentage of their wastewater.

\section{Total Volume of Water Utilize Per Day by Vehicle Washing Industry}

In determining the average daily volume of water used by vehicle washing industry, the average quantity of water used to wash individual categories of vehicles (Fig. 3) and the number of vehicles washed daily (Fig. 2 ) are used. The average volume of water used daily for vehicle washing in the Cape Coast metropolis was computed using the formula below and shown in Table 2:

Total volume of water = quantity of water used to wash a vehicleXthe number of vehicles washed daily 
Table 2: Volume of water used for washing vehicles daily

\begin{tabular}{|c|c|c|c|c|c|}
\hline \multirow[t]{2}{*}{ Type of Vehicle } & \multirow[t]{2}{*}{$\begin{array}{l}\text { Average quantity of water } \\
\text { used for washing (Litres) }\end{array}$} & \multicolumn{2}{|c|}{$\begin{array}{l}\text { No. of vehicles } \\
\text { washed per day }\end{array}$} & \multicolumn{2}{|c|}{$\begin{array}{l}\text { Volume of water for } \\
\text { washing vehicles daily } \\
\text { (Litres) }\end{array}$} \\
\hline & & $\begin{array}{l}\text { Good } \\
\text { Day }\end{array}$ & Bad Day & Good Day & Bad Day \\
\hline Saloon cars & 162.0 & 125 & 42 & $20,250.00$ & $6,804.00$ \\
\hline Four wheel drives & 184.5 & 48 & 26 & $8,856.00$ & $4,797.00$ \\
\hline Mini Buses & 207.0 & 35 & 14 & $7,245.00$ & $2,898.00$ \\
\hline Big Busses & 243.0 & 23 & 9 & $5,589.00$ & $2,187.00$ \\
\hline Tipper Trucks & 532.0 & 17 & 5 & $9,044.00$ & $2,660.00$ \\
\hline
\end{tabular}

From Table 2, about 50,984.00 litres $(5.984 \mathrm{~m} 3)$ of water is used in washing vehicles on a good day whiles about 19,346.00 litres (19.346 m3) of water is used during bad days. The World Health Organization recommended water consumption for all uses is 20 litres per capita per day [25]. For water users with household connection Abraham, et al. [26] and Lamptey [27] estimated a water consumption in a range of 60 to 120lpcd in Accra. A feasibility study conducted by Mott Mac Donald and Tremolet Consulting [24] puts the standard water consumption for household connection at 60lpcd for Ghana. Using the standard 60lpcd water consumption, the daily total volume of water used for vehicle washing will be able to serve 322 - 850 people with household connection daily. The number of people could be more if they fetch water from a yard connection and public standpipe.

\section{Water Conservation in the Commercial Vehicle Washing Industry}

In Ghana, there are no water efficiency regulations in place for the vehicle washing industry. The only environmental requirement enforced by law is the prescribe standards and guidelines relating to the discharge of untreated wastes and control of toxic substances into drains under the Environmental Protection Agency Act (Act 490). EPA is only able to enforce Act 490 when the washing bay is attached to a fuel station. Abraham [9] reports of a serious violation of the EPA Act (Act 490) by the vehicle washing bays. The general observations made at various washing bays in the Cape Coast metropolis revealed that wastewater from washing operations is discharged directly into drains which eventually end up into the rivers and streams untreated. Since there is no law enjoining washing bay operators to conserve or reclaim their wastewater, the operators of these businesses are not motivated to employ water conservation strategies. Zaneti, et al. [18] have stated that in the developed world, there are institutional arrangements for certification and water rebate programs in countries such as USA and Canada, where vehicle wash operators are made to comply with conservation techniques (water saving equipment, spray nozzle replacement, prompt repair of leaks, water reclamation) and receive rebates of up to $50 \%$. Other advantages of these incentives are technical support, protection from shutdown during advanced droughts and signs identifying the vehicle wash operator as a recognized water saving partner.

In Queensland, Australia, it is mandatory to use at most 70 litres of fresh water in a single car wash [28-31]. Compliance with this water efficiency guideline is demonstrated by the operator keeping a weekly written record of the number of vehicles washed and the amount of water used. Some of the sanctions include the closure of the business. In Germany, state policy instruments exists that support the operations of the 
vehicle washing bay [32]. In Europe, some countries (Netherlands and the Scandinavian countries) restrict the water consumption to $60-70$ litres per car and/or impose reclamation percentage (70-80\%) [30]. Also in Belgium, a recycling percentage of $70 \%$ is needed to obtain an environmental license and this has led to nearly $15 \%$ of the Belgian carwashes already purifying and re-using 55\% of their wastewater [30].

\section{Research Findings}

The research is aimed at assessing the water use and conservation by the commercial vehicle washing industry in the Cape Coast metropolis of Ghana.

Commercial vehicle washing industry in the Cape Coast metropolis uses high pressure washing machine and bucket. The vehicles are mounted on ramps connected to public drains or wetlands. The method is purely manual leading to several disturbing issues such as long washing time, limited number of vehicles washed per day, excessive water and detergent use and the discharge of excessive quantity of wastewater (containing soap, sand particles, residues from exhaust fumes and engine oils, etc.).

On the average, a minimum of 96 vehicles are washed daily in the metropolis with majority of them being saloon cars. An average 162 - 532 litres of water is used to wash a single vehicle utilizing an estimated 19,346.00 litres (minimum) of treated water. Over $70 \%$ of the water used for washing vehicles are sourced from Ghana Water Company Limited (GWCL). The volume of water used by the commercial vehicle washing industry is very high creating competition with critical sectors of the economy such as health facilities, households, institutions etc. There is therefore the need to regulate the water usage by this equally important industry.

Currently, there are no water efficiency regulations in place for the commercial vehicle washing industry. In addition, the enforcement of the Environmental Protection Agency Act (Act 490) by the EPA is limited only to commercial vehicle washing bays attached to fuel stations. The lack of water efficiency and conservation regulations serves as a disincentive for owners of commercial vehicle washing bays to conserve water and/or reclaim their wastewater.

As the population is increasing and people's ability to purchase private vehicles is rising, the number of vehicles is likely to double in the coming years. The negative effects of the industry such as high water usage and wastewater generation need to be regulated. There is urgent need for central Government to enact laws to compel the owners of vehicle washing bays to regulate the amount of water used for washing and ensure reclamation of vehicle wash wastewater. The country can emulate the examples of US, Canada, Germany, Netherlands, Australia, Belgium etc. in regulating the commercial vehicle washing industry in Ghana.

\section{References}

[1] G. E. Brown, "Statement on 2016 World Water Day and White House Water Summit," ed: Office of Governor of State of California, 2016.

[2] S. Ghizellaoui, M. Euvrard, J. Ledion, and A. Chibani, "Inhibition of scaling in the presence of copper and zinc by various chemical processes," Desalination, vol. 206, pp. 185-197, 2007.

[3] J. Brasino and J. Dengler, "Practical" fish toxicity test report," EPI (Environmental Partners, Inc.), Issaquah, WA. 10pp, 2007.

[4] H. Janik and A. Kupiec, "Trends in Modern Car Washing," Polish Journal of Environmental Studies, vol. 16, pp. 927-931, 2007.

[5] S. Edusah and D. Simon, "Land use and land allocation in Kumasi peri-urban villages," CEDAR/IRNR Kumasi paper, vol. 9, 2001.

[6] D. McGregor, D. Simon, and D. Thompson, "Peri-urban natural resources management at the watershed level: Kumasi," Ghana2002.

[7] S. S. Sandow, "Title," unpublished|.

[8] California Environmental Protection Agency, "DWQ Waste Discharge Requirements for Dischargers of Storm Water Associated with Industrial Activities, Draft Wording, Monitoring Program and Reporting Requirements," in Staff Proposal for Modification to Water Quality Order No. 91-13, ed. California, USA: California Environmental Protection Agency, 1992. 
[9] B. Abraham. (2011). Water containment, detailers and the EPA. Available: http://www.carwash.com/articles/water-containment-detailers-and-the-epa-4

[10] P. Appiah-Kubi, "Water Company to Close down Car Washing bays," ed: Modern Ghana, 2001.

[11] E. Tetteh-Addison. (2012). Vehicle Population and International Trend. Available: http://staging.unep.org/transport/pcfv/PDF/Ghana_2012/VehiclePopulation_Trends.pdf

[12] K. A. Zotter, "“End-of-pipe" versus "process-integrated" water conservation solutions: A comparison of planning, implementation and operating phases," Journal of cleaner production, vol. 12, pp. 685-695, 2004.

[13] R. F. Dunn and G. E. Bush, "Using process integration technology for CLEANER production," Journal of cleaner production, vol. 9, pp. 1-23, 2001.

[14] Ghana Statistical Service, "2010 Population and Housing Census: Summary Reports of Final Results," Ghana Statistical Service, Accra, Ghana2012.

[15] L. R. Gay and G. E. Mills, Educational Research: Competencies for Analysis and Applications, Global Edition: Edition 11: Pearson Education Limited, 2015.

[16] Indian National Environment Commission, "General Information and Guidelines for Vehicle Wash Facility in Bhutan," ed. New Delhi, India: Royal Government of Bhutan, 2001.

[17] C. Brown, "Water conservation in the professional car wash industry," Chicago: International Carwash Association, 2000.

[18] R. Zaneti, R. Etchepare, and J. Rubio, "Car wash wastewater reclamation. Full-scale application and upcoming features," Resources, Conservation and Recycling, vol. 55, pp. 953-959, 2011.

[19] A. P. Obeng, P. Dwamena-Boateng, and J. D. Ntiamoah-Asare, "Alternative drinking water supply in low-income urban settlements using tankers: A quality assessment in Cape Coast, Ghana," Management of Environmental Quality: An International Journal, vol. 21, pp. 494-504, 2010.

[20] E. Awere and G. K. Anornu, "The Contribution of Water Tanker Operations towards the Health of Water Consumers in the Cape Coast Metropolis of Ghana. ," International Journal of Environmental Sciences, vol. 7, pp. 105-112, 2016.

[21] M. Panizza and G. Cerisola, "Applicability of electrochemical methods to carwash wastewaters for reuse. Part 1: Anodic oxidation with diamond and lead dioxide anodes," Journal of Electroanalytical Chemistry, vol. 638, pp. 28-32, 2010.

[22] K. Karakulski and A. Morawski, "Treatment of wastewater from car washes by ultrafiltration," Fresenius Environmental Bulletin, vol. 12, pp. 343-348, 2003.

[23] C. Y. Chang, "Recycling and Reutilization of Municipal Water Resources," A report submitted to National Science Council, Taipei, Taiwan2005.

[24] Mott Mac Donald and Tremolet Consulting, "EIB-AFD Ghana Rural Water Supply and Sanitation Program. Feasibility Study Volume 1," EIB-AFD2012.

[25] Safe Water Network, "Market Assessment: Market-Based Provision of Water at the Community Level in Ghana. Final Report," Safe Water Network Accra, Ghana2013.

[26] E. M. Abraham, D. Van Rooijen, O. Cofie, and L. Raschid-Sally, "Planning urban water-dependent livelihood opportunities for the poor in Accra, Ghana," in SWITCH Scientific Meeting, 2007, pp. 9-10.

[27] F. Lamptey, "Title," unpublished|.

[28] Queensland Water Commission, "Standard vehicle washing: fixed commercial premises," Brisbane: Queensland Water Commission, vol. 16, 2008.

[29] Queensland Water Commission, "Large vehicle washing guideline," Brisbane: Queensland Water Commission, 2008.

[30] K. Boussu, C. Kindts, C. Vandecasteele, and B. Van der Bruggen, "Applicability of nanofiltration in the carwash industry," Separation and Purification Technology, vol. 54, pp. 139-146, 2007.

[31] T. Hamada and Y. Miyazaki, "Reuse of carwash water with a cellulose acetate ultrafiltration membrane aided by flocculation and activated carbon treatments," Desalination, vol. 169, pp. 257-267, 2004.

[32] L. Partzsch, "Smart regulation for water innovation-the case of decentralized rainwater technology," Journal of Cleaner Production, vol. 17, pp. 985-991, 2009. 